\title{
SpS9: Future Large Scale Facilities
}

No contribution was received from this Joint Discussion. 